\title{
GASTRORETENTIVE FLOATING TECHNOLOGY FOR ERADICATION OF HELICOBACTER PYLORI: AN INSIGHT VIEW
}

\section{RAKESH PAHWA ${ }^{*}$, BIGUL YOGESHVER BHARDWAJ ${ }^{1}$, ARCHANA SHARMA $^{1}$, MONA PIPLANI $^{2}$, MANISH KUMAR $^{3}$}

1Institute of Pharmaceutical Sciences, Kurukshetra University, Kurukshetra, Haryana, 136119 India, ${ }^{2}$ School of Pharmacy, Maharaja Agrasen University, Baddi, Dist, Solan, Himachal Pradesh, 174103 India, ${ }^{3}$ M M College of Pharmacy, Maharishi Markandeshwar (Deemed to be University), Mullana, Haryana, 133207 India

Email: rakesh_pahwa2407@yahoo.co.in

Received: 12 Aug 2020, Revised and Accepted: 13 Feb 2021

\section{ABSTRACT}

Helicobacter pylori is a virulent human pathogen infecting about $50 \%$ of the population worldwide. Being a leading cause of gastric ulcer, duodenal ulcer, gastritis, dyspepsia, gastric tumorigenesis etc., this organism has been the focus of concerted study to establish uncertainty of its genetics, immunopathogenesis and cell biology. Scientists have tried to effectively eradicate this pathogen from the gastrointestinal tract in various manners. Inquest of this venture, gastroretentive drug delivery systems including floating dosage forms have emerged as a boon and offer significantly improved therapeutic effects of different antimicrobial drugs. This article presents an evocative review of the structural features, epidemiological evidences and various pharmacotherapeutics vistas. In addition, various novel gastroretentive dosage forms developed so far to combat Helicobacter pylori infection are also discussed. Comprehensive literature review has been performed for this manuscript by utilizing relevant databases like PubMed, SCOPUS, Web of Science, Science Direct, Google Scholar etc., from 1997 up to the year 2020.

Keywords: Helicobacter pylori, Gastric ulcer, Pharmacotherapeutic vistas, Gastroretentive technology, Floating dosage forms

(C) 2021 The Authors. Published by Innovare Academic Sciences Pvt Ltd. This is an open access article under the CC BY license (https://creativecommons.org/licenses/by/4.0/) DOI: https://dx.doi.org/10.22159/ijap.2021v13i3.39369. Journal homepage: https://innovareacademics.in/journals/index.php/ijap

\section{INTRODUCTION}

Helicobacter pylori (H. pylori) is a spiral-shaped, micro-aerophilic and gram-negative bacteria. Campylobacter pyloridis is the earlier name of this pathogen, however; a new class has been introduced and currently, $H$. pylori is included in the family Helicobacteraceae, helicobacter genus [1, 2]. Helicobacter pylori bacterium was initially identified in human populations in 1906 and successfully cultured in 1982 by Marshall and Warren, who jointly received 2005 Nobel Prize for their research on Helicobacter pylori [3-7]. This pathogen exists in the gastric mucous overlying the epithelium of the stomach, in more than 50 percent population of the entire world [8-12]. Colonization of $H$. pylori in the gastric region causes chronic gastric inflammation in all infected persons, with the clinical indication in 10-20 percent [1].

\section{Helicobacter pylori infection associated ailments}

Infection associated with $H$. pylori includes peptic ulcers (duodenal ulcers and gastric ulcers), severe, recurrent and atrophic gastritis, gastric B cell lymphoma, gastric adenocarcinoma, intestinal metaplasia, mucosa-associated lymphoid tissue (MALT)-associated lymphoma etc [1, 13-19]. Typhoid fever has also independently associated with $H$. pylori [20]. Earlier epidemiologic evidence indicates that $H$. pylori infection increases the risk of gastric cancer. It has also been investigated that bacterium Helicobacter pyloriinduced infection is carcinogenic to human population [19, 21-26]. DNA damage caused by this bacterium may lead to the cancer development in the stomach. Earlier studies revealed that genomic regions demonstrate more susceptibility to $H$. pylori induced DNA disruption and are substantially associated with chromosomal modifications in stomach cancer $[27,28]$. Some virulence factors are also responsible for chromosomal changes. Two of the main significant virulence factors include cytotoxin-associated gene A (CagA) and vacuolating cytotoxin (VacA) [5, 29-32]. Multiple findings suggest that Helicobacter pylori infection is correlated with a substantially higher risk of stomach cancer and longer the time interval between detection of Helicobacter pylori and diagnosis of stomach cancer, greater the risk of developing carcinoma [33]. Flagella and spiral structure of $H$. pylori allows selective adherence to the epithelium through gastrointestinal mucus gel $[11,13,34]$. Drinking water can also be a risk factor for bacterial transmission [35]. Moreover, H. pylori have also been cultured through vomitus, diarrheal stool and saliva [36]. Ailments related to Helicobacter pylori infection is presented in fig. 1.

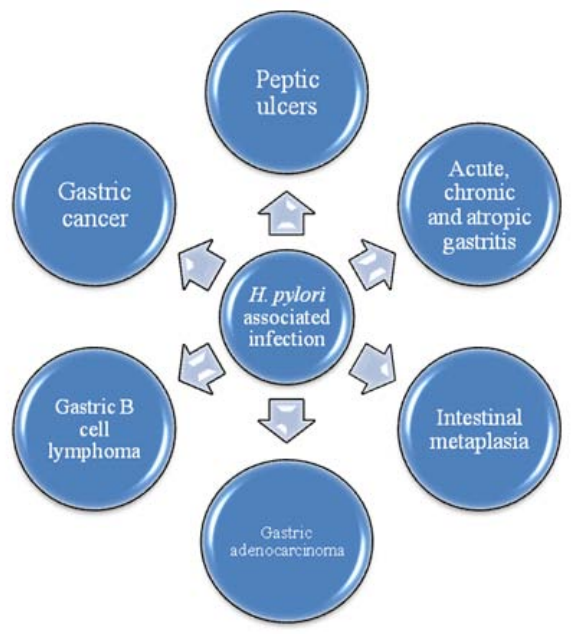

Fig. 1: H. pylori associated various ailments

\section{Immunological defence mechanisms against bacterial proliferation}

Several factors produced by mucosa of the stomach inhibit bacterial proliferation. Antibacterial peptides are active against several specific types of bacteria, which include LL37 and $\beta$ defensins 1 and 2. Lactoferrin also hampers bacterial development. Lactoferricin, a lactoferrin-derived peptide, also has antimicrobial qualities. Lysozyme can also be responsible for bacterial peptidoglycan degradation [37]. By diminishing inflammation grades and bacterial population, the antimicrobial peptide cathelicidin may serve as a natural antibiotic against $H$. pylori. Another proposed method of managing Helicobacter pylori infection is to use fatty acids, as numerous experiments have demonstrated their antibacterial activity [27]. The binding of $H$. pylori to 
gastrointestinal epithelial cells leads to triggering activation of various signalling mechanisms, which enables the effective transmission of toxic substances or other contaminants into gastric epithelium cells [37]. Findings in various animal models suggest that H. pylori's attachment to gastric epithelial cells affects the growth of inflammation in gastric mucosa, production autoantibodies, parietal cell diminution etc [37]. Urease and flagella are two crucial virulence factors for colonization of Helicobacter pylori successfully into the stomach [38]. Urease enzyme produced by Helicobacter pylori is responsible for mononuclear phagocytes activation along with enhancement in production of inflammatory cytokine, which creates favourable environment for bacteria to colonize [39, 40]. Diagnosis of infection is usually performed by diagnostic tests such as stool antigen test, urea breath test, blood antibody test etc $[41,42]$. These tests determine whether a bacterial infection may induce ulcer or inflammation of stomach lining and also establish the effectiveness of the treatment strategies [43].

\section{Treatment strategies}

Several years ago, dual therapies which combined a proton pump inhibitor with either clarithromycin or amoxicillin were common. A large number of triple or quadruple treatments have also been reported. Triple therapy to eradicate Helicobacter pylori infection includes a metronidazole (or tinidazole), proton pump inhibitor along with clarithromycin. Few probiotic strains may minimize the probability of adverse effects and thus enhance the eradication rate of Helicobacter pylori [15, 24, 44-48]. In between 10-20 percent of cases, the most utilized medication regimens may also struggle. Quadruple therapy based on bismuth remains the primary choice for second-line treatment if not used as first-line therapy [15, 43, 47, 4953]. Recently, many researchers have an ultimate aim for considering $H$. pylori genomics for the development of new therapies. One example of this includes developing targeted interventions that eliminate $H$. pylori without disrupting commensal human bacteria. For example, recent work has identified HtrA and BioV (a synthetic biotin enzyme) as specific to $H$. pylori. These have potential for allowing the treatment of $H$. pylori without affecting the host or the resident microbiota [54]. It was also found that eating broccoli sprouts daily for two month can reduces $H$. pylori infection into the stomach [55]. It was reported that a Korean vegetable Kimichi may also eradicate H. pylori [56].

Sometimes, several therapies to eradicate $H$. pylori are difficult and complex. Increased and indiscriminate utilization of antibiotics has led to significant failures in treatment [43]. Owing to high antibiotics resistance and inadequate patient compliance, new medications with enhanced efficacy in addition to simpler regimens are desired for the eradication of Helicobacter pylori [53]. Therefore, to attain a high wipeout rate of $H$. pylori from the stomach, it's obligatory that delivery of antibiotic to the whole surface of the abdomen is achieved and consequently, drug should reach in the desired amount for adequate time to destroy the bacterium. Gastroretentive drug delivery system is employed as a promising technology to provide advantageous results in site-specificity of antibiotics delivery. Retention of the delivery system is also ensured at a particular part of the gastrointestinal tract, wherever it is needed for local delivery and action at specific site [39].

\section{Gastroretentive drug delivery systems}

The oral route is recognized as the most preferred route for drug delivery. This route has many inherent advantages like convenience, cost-effectiveness, non-invasiveness, safety and patient compliance [57-59]. However, bioavailability of medicaments delivered through this route can change considerably, particularly if pharmacotherapeutic substances are delivered utilizing conventional types. Such constraints are usually due to inter-and intra-subject variability in the physiology of the gastrointestinal tract, gastrointestinal tract transit period and in certain instances to region-specific (narrow absorption window) of drug [60]. However, modern technical development has resulted into various emerging pharmaceutical strategies, especially controlled release systems to effectively resolve this issue $[61,62]$. Due to tremendous therapeutic benefits, orally controlled dosage forms have been developed in the previous few years [63-65]. Gastroretentive technology is one illustration where characteristics such as prolonged gastric retention combined with controlled-release medication dramatically increased patient compliance [61, 66-68].

Extent of drug absorption from duodenum and jejunum is minimal, as transit through this area is fast. This phenomenon drastically limits the success of conventional delivery system [69, 70]. The failure of conventional approaches in gastric retention has contributed to the production of gastroretentive technologies. These delivery systems have been engineered to maintain an extended interval of time in the upper gastrointestinal tract, after which drugs are released into a controlled manner. Prolonged interaction of gastroretentive devices with absorption layer permits improved bioavailability of medicament $[39,71-73]$. Such devices are especially useful for drugs predominantly absorbed in the regions of the duodenum and upper jejunum [69]. Various technical strategies have been explored in order to establish delivery systems that can be retained into the stomach. These methods have been suggested for improving retention in upper section of the gastrointestinal tract [74]. These gastroretentive dosage forms are classified into various approaches as shown in fig. 2, such as floating systems [7577], expandable systems [78, 79], bioadhesive systems [80-83], highdensity systems [84, 85], superporous hydrogels [78, 86], magnetic systems [86, 87], dual working systems $[88,89]$ etc.

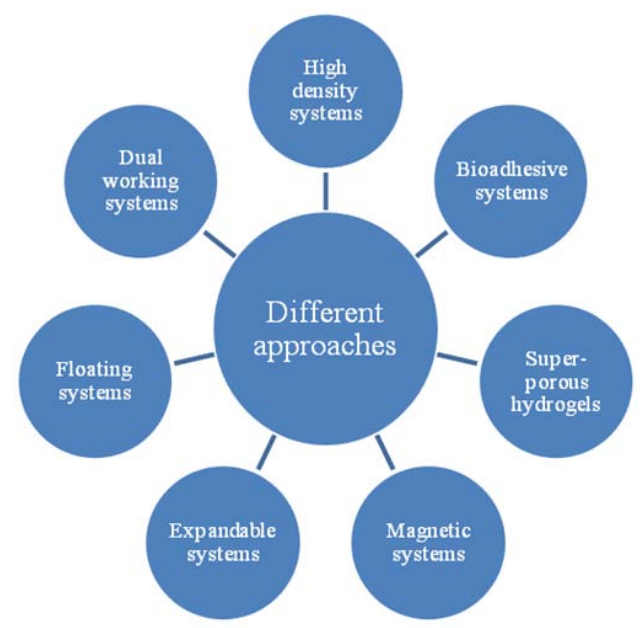

Fig. 2: Different approaches of gastroretentive drug delivery systems

\section{Advantages of gastroretentive strategies}

Gastroretentive technologies are gaining popularity due to numerous advantages and patient compliance benefits. Some significant benefits of this system are mentioned in the subsequent section. Various narrow absorption window drugs may show advantageous results after compounding into gastroretentive dosage forms. Maximum drug utilization with limited negative consequences, low dosing frequency thus improved patient compliance besides controlled drug release behavior present the benefits of continuous and uniform blood drug level. The medication concentration variability is also significantly reduced. In addition, side effects based on dosage may also be minimized [90-95].

\section{Salient benefits}

Following are some important benefits of gastroretentive delivery systems [95-98].

- Enhancing bioavailability as well as the therapeutic efficacy of molecules with narrow absorption window in the upper gastrointestinal tract.

- Enhanced utilization of medicaments with limited side effects.

- Low dosing frequency thus improved patient comfort and compliance. 
- Controlled drug release behavior provides uniform and consistent blood level of medication.

- Variations in drug concentration are reduced. Hence, concentrationdependent side effects may be minimized.

- Avoiding gastric irritation due to sustained release profile.

- Site specificity.

- Uniform release of the drug without risk of dose dumping.

- Reduced inter-and intra-subject variability.

- Increased stomach retention period owing to buoyancy principle, circumventing the invariable and inadequate absorption of drugs.

- Versatility in the design of dosage form.

- Extended patent rights along with emerging newer market prospect.

\section{Current viewpoint on gastroretentive approaches}

Various gastroretentive drug delivery systems have been investigated for successful gastric retention. However, alteration in gastric retention time, especially in fed as well as fasted state, is still one of the major challenges for the scientists. Therefore, it is advantageous to explore suitable innovative gastroretentive approaches by overcoming the drawbacks of a particular approach. Various combined approaches might be a beneficial strategy for reducing the irregularity of gastric retention time. Also, coupled working system is less affected due to physiological state of the gut for instance, as in fed and fasting conditions. These advanced systems may ensure delayed gastric empting. Therefore, a study on gastroretentive drug delivery systems in the near future should be with major concern of combining various strategies to achieve desired stomach retention of dosage forms also in fasted condition $[39,89,99,100]$. The use of newer techniques such as extrusion and amalgamation of various approaches will further create interest in gastroretentive drug delivery systems and it will continue to create interest among pharmaceutical industries and researchers [57]. Various gastroretentive floating drug delivery systems investigated for Helicobacter pylori eradication are portrayed in fig. 3.

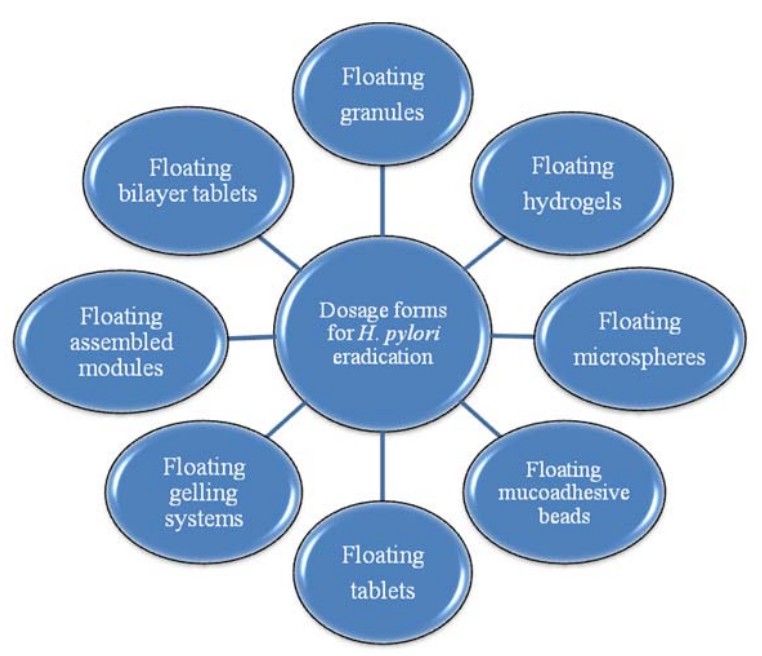

Fig. 3: Various floating dosage forms for eradication of $\mathrm{H}$. pylori

Miscellaneous research considerations on eradication of Helicobacter pylori through gastroretentive techniques have been published. Few of these findings are presented in table 1.

Table 1: Gastroretentive drug delivery approaches for eradication of Helicobacter pylori

\begin{tabular}{|c|c|c|c|c|c|}
\hline S. No. & Drug & Dosage form & Authors & Year & Ref. (s) \\
\hline 1. & Levofloxacin hydrochloride & Gastroretentive wafers & Li et al. & 2020 & {$[101]$} \\
\hline 2. & Amoxicillin trihydrate & Floating mucoadhesive alginate beads & Dey et al. & 2016 & {$[102]$} \\
\hline 3. & Metronidazole & Floating $\mathrm{pH}$-sensitive chitosan hydrogel & El Mahrouk et al. & 2016 & {$[103]$} \\
\hline 4. & Amoxicillin and clarithromycin & Floating assembled modules & Rossi et al. & 2016 & {$[104]$} \\
\hline 5. & Amoxicillin trihydrate & Floating mucoadhesive beads & Thombre et al. & 2016 & {$[105]$} \\
\hline 6. & Clarithromycin & Floating mucoadhesive alginate beads & Adebisi et al. & 2015 & [106] \\
\hline 7. & Clarithromycin & Floating fine granules & Aoki et al. & 2015 & {$[107]$} \\
\hline 8. & Clarithromycin & Floating tablets & Ugurlu et al. & 2014 & [108] \\
\hline 9. & Clarithromycin & Floating mucoadhesive beads & Gattani et al. & 2010 & [109] \\
\hline 10. & Metronidazole & Floating alginate beads & Javadzadeh et al. & 2010 & {$[110]$} \\
\hline 11. & Clarithromycin & Gellan gum-based floating beads & Rajinikanth et al. & 2009 & {$[111]$} \\
\hline 12. & Amoxicillin & Gastroretentive minimatrices & Badhan et al. & 2009 & [112] \\
\hline 13. & Clarithromycin & Mucoadhesive microspheres & Jain et al. & 2009 & [113] \\
\hline 14. & Clarithromycin & Floating gelling system & Rajinikanth et al. & 2008 & {$[114]$} \\
\hline 15. & Acetohydroxamic acid & Floating gelling system & Rajinikanth et al. & 2008 & {$[115]$} \\
\hline 16. & Metronidazole & Floating alginate beads & Ishak et al. & 2007 & [116] \\
\hline 17. & Amoxicillin & Intra gastric floating gelling system & Rajinikanth et al. & 2007 & [117] \\
\hline 18. & Acetohydroxamic acid & Gellan based floating beads & Rajinikanth et al. & 2007 & [118] \\
\hline 19. & Amoxicillin & Mucoadhesive microspheres & Patel et al. & 2007 & [119] \\
\hline 20. & Metronidazole & Floating emulsion gel beads & Sriamornsak et al. & 2005 & {$[120]$} \\
\hline 21. & Acetohydroxamic acid & Floating microspheres & Umamaheshwari et al. & 2003 & {$[121]$} \\
\hline 22. & Acetohydroxamic acid & Floating mucoadhesive microspheres & Umamaheshwari et al. & 2002 & {$[122]$} \\
\hline 23. & Ampicillin & $\begin{array}{l}\text { Floating sustained release liquid } \\
\text { preparation }\end{array}$ & Katayama et al. & 1999 & [123] \\
\hline 24. & Tetracycline and metronidazole & Floating tablets & Yang et al. & 1999 & {$[124]$} \\
\hline
\end{tabular}

\section{CONCLUSION}

H. pylori is a global pathogen and its infection causes various clinical and pathological effects involving chronic gastritis, peptic ulcer, malignant stomach tumours etc. Development of an efficient gastroretentive dosage form is a real challenge for the eradication of bacterium by delivering suitable antibiotic in the stomach. The present review provides an insight of different aspects of this spiral gram-negative bacterium along with various antibiotic regimens available for the treatment of infection prevailing in all classes of people around the world. Immense potential of promising gastroretentive technologies for eradication of this prevalent contagion are highlighted in the current manuscript. Various research endeavours in the avenue of gastroretentive drug delivery 
ensuring maximal absorption of the antibiotic for eradication of the bacterium have also been discussed.

\section{FUTURE PERSPECTIVES}

Advancements are needed on technical and scientific aspects in this area for the development of novel and versatile gastroretentive dosage forms so as to eradicate the bacterium efficiently and successfully. It is also emphasized that sophisticated research based on enhanced stability profile and prolonged residence time of dosage forms should be investigated to achieve better penetration of antibiotics through the stomach mucus layer to act on $H$. pylori. Progress in synergistic approaches utilizing superior drug delivery technologies may prove a useful prospect for improved pharmacotherapy of this complex infection. In addition, further additional in vivo studies are required to establish the suitability of gastroretentive formulations for targeting actives to the gastric wall. Moreover, studies regarding antibiotics delivery to target receptor sites on $H$. pylori or circumvent the adhesion of bacteria to the gastric wall should also be focused.

\section{FUNDING}

Nil

\section{AUTHORS CONTRIBUTIONS}

All the authors have contributed equally.

\section{CONFLICT OF INTERESTS}

No conflict of interest

\section{REFERENCES}

1. Proenca Modena JL, Acrani GO, Brocchi M. Helicobacter pylori: phenotypes, genotypes and virulence genes. Future Microbiol 2009;4:223-40.

2. Fang Y, Fan C, Xie H. Effect of Helicobacter pylori infection on the risk of the acute coronary syndrome: a systematic review and meta-analysis. Medicine 2019;98:18348-59.

3. Kang SJ, Kim DH, Lee BJ. NMR study on small proteins from Helicobacter pylori for antibiotic target discovery: a review. Molecules 2013;18:13410-24.

4. Dunn BE, Cohen H, Blaser MJ. Helicobacter pylori. Clin Microbiol Rev 1997;10:720-41.

5. Bridge DR, Merrell DS. Polymorphism in the Helicobacter pylori CagA and VacA toxins and disease. Gut Microbes 2013;4:101-17.

6. Lee DS, Moss SF. Targeting Helicobacter pylori in gastric carcinogenesis. Expert Opin Ther Targets 2007;11:757-69.

7. Herszenyi L, Bakucz T, Barabás L, Tulassay Z. Pharmacological approach to gastric acid suppression: past, present, and future. Dig Dis 2020;38:104-11.

8. Kabir S. The current status of Helicobacter pylori vaccines: a review. Helicobacter 2007;12:89-102.

9. Torres J, Perez GP, Ximenez C, Munoz L, Camorlinga Ponce M, Ramos $\mathrm{F}$, et al. The association of intestinal parasitosis and $H$. pylori infection in children and adults from a mexican community with a high prevalence of parasitosis. Helicobacter 2003;8:179-85.

10. Kumar S, Kumar A, Dixit VK. Evidences showing association of interleukin-1B polymorphisms with increased risk of gastric cancer in an Indian population. Biochem Biophys Res Commun 2009;387:456-60.

11. Lai FP, Tu YF, Sheu BS, Yang YJ. Maternal H. pylori seropositivity is associated with gestational hypertension but is irrelevant to fetal growth and development in early childhood. BMC Pediatr 2019;19:501-10.

12. Pachathundikandi SK, Tegtmeyer N, Arnold IC, Lind J, Neddermann M, Falkeis-Veits $\mathrm{C}$, et al. T4SS-dependent TLR5 activation by Helicobacter pylori infection. Nat Commun 2019;10:1-11.

13. Umamaheshwari RB, Jain NK. Receptor-mediated targeting of lipobeads bearing acetohydroxamic acid for eradication of Helicobacter pylori. J Controlled Release 2004;99:27-40.

14. Ben Mansour K, Fendri C, Battikh H, Garnier M, Zribi M, Jlizi A, et al. Multiple and mixed Helicobacter pylori infections: comparison of two epidemiological situations in tunisia and france. Infect Genet Evol 2016;37:43-8.
15. Bazzoli F, Bianchi Porro G, Bianchi MG, Molteni M, Pazzato P, Zagari RM. Treatment of Helicobacter pylori infection. Indications and regimens: an update. Dig Liver Dis 2002;34:70-83.

16. Egemen A, Yilmaz O, Akil I, Altuglu I. Evaluation of association between hepatitis a and Helicobacter pylori infections and routes of transmission. Turk J Pediatr 2006;48:135-9.

17. Cardenas VM, Boller F, Roman GC. Helicobacter pylori, vascular risk factors and cognition in US older adults. Brain Sci 2019;9:370-86.

18. Shinmura T, Adachi K, Yamaguchi Y, Izawa S, Hijikata Y, Ebi M. Vonoprazan-based triple-therapy could improve the efficacy of the tailored therapy of Helicobacter pylori infection. I Gastrointestin Liver Dis 2019;28:389-95.

19. Annibale B, Capurso G, Delle Fave G. Consequences of Helicobacter pylori infection on the absorption of micronutrients. Dig Liver Dis 2002;341:72-7.

20. Vollaard AM, Verspaget HW, Ali S, Visser LG, Veenendaal RA, Van Asten HA, et al. Helicobacter pylori infection and typhoid fever in Jakarta, Indonesia. Epidemiol Infect 2006;134:163-70.

21. Shinohara K, Miyazaki K, Noda N, Saitoh D, Terada M, Wakasugi H. Gastric diseases related to Helicobacter pylori and epstein barr virus infection. Microbiol Immunol 1998;42:415-21.

22. De Falco M, Lucariello A, Iaquinto S, Esposito V, Guerra G, De Luca A. Molecular mechanisms of Helicobacter pylori pathogenesis. J Cell Physiol 2015;230:1702-7.

23. Kim A, Servetas SL, Kang J, Kim J, Jang S, Choi YH, et al. Helicobacter pylori outer membrane protein, HomC, shows geographic dependent polymorphism that is influenced by the Bab family. J Microbiol 2016;54:846-52.

24. Gong Y, Yuan Y. Resistance mechanisms of Helicobacter pylori and its dual target precise therapy. Crit Rev Microbiol 2018;44:1-22.

25. Bin Saeed AA. Is there a link between seropositivity to Helicobacter pylori and hepatitis A virus? a systematic review. Int J Infect Dis 2010;14:567-71

26. Gonzalez A, Casado J, Chueca E, Salillas S, Velazquez Campoy A, Espinosa Angarica V, et al. Repurposing dihydropyridines for treatment of Helicobacter pylori infection. Pharmaceutics 2019;11:681-99.

27. Backert $S$, Neddermann $M$, Maubach G, Naumann $M$. Pathogenesis of Helicobacter pylori infection. Helicobacter 2016;21:19-25.

28. De Bernard M, Josenhans C. Pathogenesis of Helicobacter pylori infection. Helicobacter 2014;19:11-8.

29. Greenfield LK, Jones NL. Modulation of autophagy by Helicobacter pylori and its role in gastric carcinogenesis. Trends Microbiol 2013;21:602-12.

30. Burucoa C, Axon A. Epidemiology of Helicobacter pylori infection. Helicobacter 2017;22:1-5.

31. Cid TP, Fernandez MC, Benito Martinez S, Jones NL. Pathogenesis of Helicobacter pylori infection. Helicobacter 2013;18:12-7.

32. Chang WL, Yeh YC, Sheu BS. The impacts of H. pylori virulence factors on the development of gastroduodenal diseases. J Biomed Sci 2018;25:68-77.

33. Zhang Y, Zhou X, Zhang Q, Zhang Y, Wang X. Involvement of NF$\kappa \mathrm{B}$ signaling pathway in the regulation of PRKAA1-mediated tumorigenesis in gastric cancer tumorigenesis in gastric cancer. Artif Cells Nanomed Biotechnol 2019;47:3677-86.

34. Atherton JC, Blaser JM. Coadaptation of Helicobacter pylori and humans ancient history, modern implications. J Clin Invest 2009;119:2475-87.

35. Queralt N, Araujo R. Analysis of the survival of H. pylori within a laboratory-based aquatic model system using molecular and classical techniques. Microb Ecol 2007;54:771-7.

36. Suzuki H, Hibi T, Marshall BJ. Helicobacter pylori: present status and future prospects in japan. J Gastroenterol 2007;42:1-15.

37. Algood HMS, Cover TL. Helicobacter pylori persistence: an overview of interactions between $H$. pylori and host immune defenses. Clin Microbiol Rev 2006;19:597-613.

38. Kusters JG, Van Vliet AH, Kuipers EJ. Pathogenesis of Helicobacter pylori infection. Clin Microbiol Rev 2006;19:449-90.

39. Adebisi AO, Conway BR. Modification of drug delivery to improve antibiotic targeting to the stomach. Ther Delivery 2015;6:741-62. 
40. Rico MR, Moreno Y, Barat JM. In vitro antimicrobial activity of immobilised essential oil components against Helicobacter pylori. World J Microbiol Biotechnol 2020;36:1-9.

41. Kiesslich R, Goetz M, Burg J, Stolte M, Siegel E, Maeurer MJ, et al. Diagnosing Helicobacter pylori in vivo by confocal laser endoscopy. Gastroenterology 2005;128:2119-23.

42. Dzierzanowska Fangrat K, Lehours P, Megraud F, Dzierzanowska D. Diagnosis of Helicobacter pylori infection. Helicobacter 2006;11:6-13.

43. Pahwa R, Nath A, Sharma PC, Kumar V, Kohli K. Impact of Helicobacter pylori on the prevalence of gastroduodenal diseases. Drug Invent Today 2010;2:258-63.

44. De Boer WA, Tytgat GNJ. Treatment of Helicobacter pylori infection. Br Med J 2000;320:31-4.

45. Homan M, Orel R. Are probiotics useful in Helicobacter pylori eradication? World J Gastroenterol 2015;21:10644-53.

46. Charoenying T, Patrojanasophon $\mathrm{P}$, Ngawhirunpat T, Rojanarata T, Akkaramongkolporn P, Opanasopit P. Fabrication of floating capsule-in-3D-printed devices as gastro-retentive delivery systems of amoxicillin. J Drug Delivery Sci Technol 2020;55:101393.

47. Chey WD, Wong BC. American college of gastroenterology guideline on the management of Helicobacter pylori infection. Am J Gastroenterol 2007;102:1808-25.

48. Harris A. Treatment of Helicobacter pylori. World J Gastroenterol 2001;7:303-7.

49. Wolle K, Malfertheiner P. Treatment of Helicobacter pylori. Best Pract Res Clin Gastroenterol 2007;21:315-24.

50. Van der Hulst R W M, Van der Ende A, Homan A, Roorda P, Dankert J, Tytgat G. Influence of metronidazole resistance on the efficacy of quadruple therapy for Helicobacter pylori eradication. Gut 1998;42:166-9.

51. Chan FK, Sung JJ, Suen R, Wu JC, Ling TK, Chung SC. Salvage therapies after failure of Helicobacter pylori eradication with ranitidine bismuth citrate-based therapies. Aliment Pharmacol Ther 2000;14:91-5.

52. Conway BR. Drug delivery strategies for the treatment of Helicobacter pylori infections. Curr Pharm Des 2005;11:775-90.

53. Verma A, Dubey J, Hegde RR, Rastogi V, Pandit JK. Helicobacter pylori: past, current, future treatment strategies with gasrtoretentive drug delivery systems. J Drug Targeting 2016;24:897-915.

54. Berthenet E, Sheppard S, Vale FF. Recent "omics" advances in Helicobacter pylori. Helicobacter 2016;21:14-8.

55. Yanaka A, Fahey JW, Fukumoto A, Nakayama M, Inoue S, Zhang $\mathrm{S}$, et al. Dietary sulforaphane-rich broccoli sprouts reduce colonization and attenuate gastritis in Helicobacter pyloriinfected mice and humans. Cancer Prev Res 2009;2:353-60.

56. Han YM, Park JM, Lee D, Oh JY, Hahm KB. Korean probiotic kimchi prevented Helicobacter pylori-associated gastric cancer in mice and human. FASEB J 2017;31:1067-71.

57. Kumar M, Kaushik D. An overview on various approaches and recent patents on gastroretentive drug delivery systems. Recent Pat Drug Delivery Formulation 2018;12:84-92.

58. Adibkia K, Hamedeyazdan S, Javadzadeh Y. Drug release kinetics and physicochemical characteristics of floating drug delivery systems. Expert Opin Drug Delivery 2011;8:891-903.

59. Wu Y, Zhang W, Huang J, Luo Z, Li J, Wang L. Mucoadhesive improvement of alginate microspheres as potential gastroretentive delivery carrier by blending with bletilla striata polysaccharide. Int J Biol Macromol 2020;156:1191-201.

60. Kotreka UK, Adeyeye MC. Gastroretentive floating drugdelivery systems: a critical review. Crit Rev Ther Drug Carrier Syst 2011;28:47-99.

61. El Nabarawi MA, Teaima MH, El-Monem RAA, El Nabarawy NA, Gaber DA. Formulation, release characteristics, and bioavailability study of gastroretentive floating matrix tablet and floating raft system of mebeverine HCl. Drug Des Dev Ther 2017;11:1081-93.

62. Pahwa R, Bisht S, Kumar V, Kohli K. Recent advances in gastric floating drug delivery technology: a review. Curr Drug Delivery 2013;10:286-98.

63. Klausner EA, Lavy E, Friedman M, Hoffman A. Expandable gastroretentive dosage forms. J Controlled Release 2003;90:143-62.
64. Mandal UK, Chatterjee B, Senjoti FG. Gastro-retentive drug delivery systems and their in vivo success: a recent update. Asian J Pharm Sci 2016;11:575-84.

65. Soni H, Ghulaxe C, Upadhyay S, Pillai S. Development and in vitro evaluation of an oral floating tablet of metronidazole. J Drug Delivery Ther 2018;8:83-6.

66. Sheikh FA, Hussain MA, Ashraf MU, Haseeb MT, Farid-ul-Haq M. Linseed hydrogel-based floating drug delivery system for fluoroquinolone: design, in vitro drug release and in vivo realtime floating detection. Saudi Pharm J 2020;28:538-49.

67. Pahwa R, Singh M, Kumar V, Kohli K. Recent advances and patent perspectives in gastroretentive technology. Recent Pat Drug Delivery Formulation 2012;6:278-90.

68. Schneider F, Koziolek M, Weitschies W. In vitro and in vivo test methods for the evaluation of gastroretentive dosage forms. Pharmaceutics 2019;11:416-45.

69. Awasthi R, Kulkarni GT. Decades of research in drug targeting to the upper gastrointestinal tract using gastro retention technologies: where do we stand? Drug Delivery 2016;23:378-94.

70. Hoffman A, Stepensky D, Lavy E, Eyal S, Klausner E, Friedman M. Pharmacokinetic and pharmacodynamic aspects of gastroretentive dosage forms. Int J Pharm 2004;277:141-53.

71. Lopes CM, Bettencourt C, Rossi A, Buttini F, Barata P. Overview on gastroretentive drug delivery systems for improving drug bioavailability. Int J Pharm 2016;510:144-58.

72. Sopyan I, Sriwidodo, Wahyuningrum R, Aliza PN. A review: floating drug delivery system as a tool to improve dissolution rate in gastric. Int J Appl Pharm 2020;12:10-3.

73. Ghoneim AM, Tadros MI, Alaa-Eldin AA. Spray-dried silica xerogel nanoparticles as a promising gastroretentive carrier system for the management of chemotherapy-induced nausea and vomiting. Int J Nanomed 2019;14:9619-30.

74. Malik R, Garg T, Goyal AK, Rath G. Polymeric nanofibers: targeted gastro-retentive drug delivery systems. J Drug Targeting 2015;23:109-24.

75. Mohapatra PR, Satyavani CH, Sahoo S. Design and development of carvedilol gastroretentive floating drug delivery systems using hydrophilic polymers and in vitro characterization. Int J Pharm Pharm Sci 2020;12:66-73.

76. Chen R, Guo X, Liu X, Cui H, Wang R, Han J. Formulation and statistical optimization of gastric floating alginate/oil/chitosan capsules loading procyanidins: in vitro and in vivo evaluations. Int J Biol Macromol 2018;108:1082-91.

77. Vasvari G, Haimhoffer A, Horvath L, Budai I, Trencsenyi G, Beresova M. Development and characterization of gastroretentive solid dosage form based on melt foaming. AAPS PharmSciTech 2019;20:1-11.

78. Mirani AG, Patankar SP, Kadam VJ. Risk-based approach for systematic development of gastroretentive drug delivery system. Drug Delivery Transl Res 2016;6:579-96.

79. Zhao S, Lv Y, Zhang J Bin, Wang B, Lv GJ, Ma XJ. Gastroretentive drug delivery systems for the treatment of Helicobacter pylori. World J Gastroenterol 2014;20:9321-9.

80. Pawar VK, Kansal S, Asthana S, Chourasia MK. Industrial perspective of gastroretentive drug delivery systems: physicochemical, biopharmaceutical, technological and regulatory consideration. Expert Opin Drug Delivery 2012;9:551-65.

81. Ishak RAH. Buoyancy-generating agents for stomach-specific drug delivery: an overview with special emphasis on floating behavior. J Pharm Pharm Sci 2015;18:77-100.

82. Raviteja G, Narayana RKVV, Baskaran M, Meghana G, Ganesh G. A mucoadhesive gastroretentive dosage form for valacyclovir. Int J Pharm Pharm Sci 2014;6:422-7.

83. Simons FJ, Wagner KG. Modeling, design and manufacture of innovative floating gastroretentive drug delivery systems based on hot-melt extruded tubes. Eur J Pharm Biopharm 2019;137:196-208.

84. Du F, Wu Y, Du F, Zhang L, Feng W, Zhao L. Construction of catechol-grafted chitosan alginate/barium sulfate microcapsules for computed tomography real-time imaging and gastroretentive drug delivery. Int $\mathrm{J}$ Nanomed 2019;14:6001-18. 
85. Prajapati ST, Patel LD, Patel CN. Polymers for floating drug delivery system. Syst Rev Pharm 2011;2:1-7.

86. Bardonnet PL, Faivre V, Pugh WJ, Piffaretti JC, Falson F. Gastroretentive dosage forms: overview and special case of Helicobacter pylori. J Controlled Release 2006;111:1-18.

87. Melocchi A, Uboldi M, Inverardi N, Briatico Vangosa F, Baldi F, Pandini S. Expandable drug delivery system for gastric retention based on shape memory polymers: development via 4D printing and extrusion. Int J Pharm 2019;571:118700.

88. Singh BN, Kim KH. Floating drug delivery systems: an approach to oral controlled drug delivery via gastric retention. J Controlled Release 2000;63:235-59.

89. Tripathi J, Thapa P, Maharjan R, Jeong SH. Current state and future perspectives on gastroretentive drug delivery systems. Pharmaceutics 2019;11:1-22.

90. Adebisi A, Conway BR. Gastroretentive microparticles for drug delivery applications. J Microencapsulation 2011;28:689-708.

91. Streubel A, Siepmann J, Bodmeier R. Drug delivery to the upper small intestine window using gastroretentive technologies. Curr Opin Pharmacol 2006;6:501-8.

92. Nayak AK, Maji R, Das B. Gastroretentive drug delivery systems: a review. Asian J Pharm Clin Res 2010;3:2-10.

93. Pawar VK, Kansal S, Garg G, Awasthi R, Singodia D, Kulkarni GT. Gastroretentive dosage forms: a review with special emphasis on floating drug delivery systems. Drug Delivery 2011;18:97110.

94. Murphy C, Pillay V, Choonara Y, Du Toit L. Gastroretentive drug delivery systems: current developments in novel system design and evaluation. Curr Drug Delivery 2009;6:451-60.

95. Prajapati VD, Jani GK, Khutliwala TA, Zala BS. Raft forming system-an upcoming approach of gastroretentive drug delivery system. J Controlled Release 2013;168:151-65.

96. Pahwa R, Saini N, Kumar V, Kohli K. Chitosan-based gastroretentive floating drug delivery technology: an updated review. Expert Opin Drug Delivery 2012;9:525-39.

97. Talukder R, Fassihi R. Gastroretentive delivery systems: a mini review. Drug Dev Ind Pharm 2004;30:1019-28.

98. Sathish D, Himabindu S, Shravan Kumar Y, Shayeda, Madhusudan Rao Y. Floating drug delivery systems for prolonging gastric residence time: a review. Curr Drug Delivery 2011;8:494-510.

99. Bera H, Maiti S, Saha S, Nayak AK. Biopolymers-based gastroretentive buoyant systems for therapeutic management of Helicobacter pylori infection. Polysaccharide Carriers Drug Delivery 2019;713-36. DOI:10.1016/B978-0-08-1025536.00024-6

100. Pahwa R, Jindal S, Chhabra L, Dutt H, Rao R. Development and in vitro characterization of effervescent floating drug delivery system of famotidine. Int J Pharm Sci Res 2012;3:241-6.

101. Li Z, Zeng R, Yang L, Ren X, Maffucci KG, Qu Y. Development and characterization of PCL electrospun membrane-coated Bletilla striata polysaccharide-based gastroretentive drug delivery system. AAPS PharmSciTech 2020;21:1-14.

102. Dey SK, De PK, De A, Ojha S, De R, Mukhopadhyay AK, et al. Floating muco adhesive alginate beads of amoxicillin trihydrate: a facile approach for $\mathrm{H}$. pylori eradication. Int J Biol Macromol 2016;89:622-31.

103. El Mahrouk GM, Abouleinien MH, Makhlouf AI. Design, optimization and evaluation of novel metronidazole loaded gastroretentive $\mathrm{pH}$ sensitive hydrogel. AAPS PharmSciTech 2016;17:1285-97.

104. Rossi A, Conti C, Colombo G, Castrati L, Scarpignato C, Barata P, et al. Floating modular drug delivery systems with buoyancy independent of release mechanisms to sustain amoxicillin and clarithromycin intra-gastric concentrations. Drug Dev Ind Pharm 2016;42:332-9.

105. Thombre NA, Gide PS. Floating-bioadhesive gastroretentive Caesalpinia pulcherrima-based beads of amoxicillin trihydrate for Helicobacter pylori eradication. Drug Delivery 2016;23:40519.
106. Adebisi AO, Laity PR, Conway BR. Formulation and evaluation of floating mucoadhesive alginate beads for targeting Helicobacter pylori. J Pharm Pharmacol 2015;67:511-24.

107. Aoki H, Iwao Y, Mizoguchi M, Noguchi S, Itai S. Clarithromycin highly-loaded gastro floating fine granules prepared by highshear melt granulation can enhance the efficacy of Helicobacter pylori eradication. Eur J Pharm Biopharm 2015;92:22-7.

108. Ugurlu T, Karacicek U, Rayaman E. Optimization and evaluation of clarithromycin floating tablets using experimental mixture design. Acta Pol Pharm 2014;71:311-21.

109. Gattani SG, Savaliya PJ, Belgamwar VS. Floating mucoadhesive beads of clarithromycin for the treatment of Helicobacter pylori infection. Chem Pharm Bull 2010;58:782-7.

110. Javadzadeh Y, Hamedeyazdan S, Adibkia K, Kiafar F, Zarrintan $\mathrm{MH}$, Barzegar-Jalali M. Evaluation of drug release kinetics and physico-chemical characteristics of metronidazole floating beads based on calcium silicate and gas-forming agents. Pharm Dev Technol 2010;15:329-38.

111. Rajinikanth PS, Mishra B. Stomach site specific drug delivery system of clarithromycin for eradication of Helicobacter pylori. Chem Pharm Bull 2009;57:1068-75.

112. Badhan AC, Mashru RC, Shah PP, Thakkar AR, Dobaria NB. Development and evaluation of sustained release gastroretentive minimatrices for effective treatment of $\mathrm{H}$. pylori infection. AAPS PharmSciTech 2009;10:459-67.

113. Jain SK, Jangdey MS. Lectin conjugated gastroretentive multiparticulate delivery system of clarithromycin for the effective treatment of Helicobacter pylori. Mol Pharmaceutics 2009;6:295-304

114. Rajinikanth PS, Mishra B. Floating in situ gelling system for stomach site-specific delivery of clarithromycin to eradicate $H$ pylori. J Controlled Release 2008;125:33-41.

115. Rajinikanth PS, Mishra B. Floating in situ gelling system of acetohydroxamic acid for clearance of $H$. pylori. Drug Dev Ind Pharm 2008;34:577-87.

116. Ishak RA, Awad GA, Mortada ND, Nour SA. Preparation, in vitro and in vivo evaluation of stomach-specific metronidazoleloaded alginate beads as local anti-Helicobacter pylori therapy. J Controlled Release 2007;119:207-14

117. Rajinikanth PS, Balasubramaniam J, Mishra B. Development and evaluation of a novel floating in situ gelling system of amoxicillin for eradication of Helicobacter pylori. Int J Pharm 2007;335:114-22.

118. Rajinikanth PS, Mishra B. Preparation and in vitro characterization of gellan based floating beads of acetohydroxamic acid for eradication of $H$. pylori. Acta Pharm 2007;57:413-27.

119. Patel JK, Patel MM. Stomach specific anti-Helicobacter pylori therapy: preparation and evaluation of amoxicillin-loaded chitosan mucoadhesive microspheres. Curr Drug Delivery 2007;4:41-50.

120. Sriamornsak P, Thirawong N, Puttipipatkhachorn S. Emulsion gel beads of calcium pectinate capable of floating on the gastric fluid: effect of some additives, hardening agent or coating on release behavior of metronidazole. Eur J Pharm Sci 2005;24:363-73.

121. Umamaheshwari RB, Jain S, Bhadra D, Jain NK. Floating microspheres bearing acetohydroxamic acid for the treatment of Helicobacter pylori. J Pharm Pharmacol 2003;55:1607-13.

122. Umamaheswari RB, Jain S, Tripathi PK, Agrawal GP, Jain NK. Floating-bioadhesive microspheres containing acetohydroxamic acid for clearance of Helicobacter pylori. Drug Delivery 2002;9:223-31.

123. Katayama H, Nishimura T, Ochi S, Tsuruta Y, Yamazaki $Y$, Shibata $\mathrm{K}$, et al. Sustained release liquid preparation using sodium alginate for eradication of Helicobacter pylori. Biol Pharm Bull 1999;22:55-60.

124. Yang L, Eshraghi J, Fassihi R. A new intragastric delivery system for the treatment of Helicobacter pylori associated gastric ulcer: in vitro evaluation. J Controlled Release 1999;57:215-22. 